\title{
Influence of time on modification effect of silumin AlSi11 with strontium and boron
}

\author{
Wpływ czasu na efekt modyfikacji siluminu AISi11 \\ strontem i borem
}

\begin{abstract}
Studies on the effect of time on the modification of AlSi11 silumin with variable strontium micro additives in the form of an AISr10 master alloy and boron in an AIB4 master alloy were investigated. The results showed that the strontium micro additive resulted in a satisfactory improvement in the $\alpha(\mathrm{Al})+\beta(\mathrm{Si})$ eutectic and an increase in tensile strength $\left(R_{m}\right)$ and unit elongation $\left(A_{5}\right)$; this is also the case two hours after adding the modifier. The simultaneous modification of silumin with AlB4 and AlSr10 causes a strong fragmentation of the alloy grains and significant improvement in $R_{m}$ and $A_{5}$ (also two hours after adding the modifiers).
\end{abstract}

Keywords: silumin, modification, structure, mechanical properties

\section{Streszczenie}

Przeprowadzono badania nad wpływem czasu na modyfikację siluminu AISi11 zmiennymi mikrododatkami strontu w postaci zaprawy AISr10 oraz boru w postaci zaprawy AIB4. Wyniki badań wykazały, że mikrododatek strontu powoduje zadowalające uszlachetnienie eutektyki $\alpha(\mathrm{Al})$ $+\beta(\mathrm{Si})$ i wzrost wytrzymałości na rozciąganie $\left(R_{m}\right)$ oraz wydłużenia względnego $\left(A_{5}\right)$, także po upływie dwóch godzin po dodaniu modyfikatora. Równoczesna modyfikacja siluminu zaprawami AlB4 i AlSr10 powoduje silne rozdrobnienie ziarn stopu i istotną poprawę $R_{m}$ oraz $A_{5}$, również po upływie dwóch godzin po dodaniu modyfikatorów.

Słowa kluczowe: silumin, modyfikacja, struktura, właściwości mechaniczne

\section{Introduction}

The properties of Al-Si cast alloys depend on the state of their structures. The decisive influence on them affect the shape, size, and distribution of the components of the structure. The properties in hypoeutectic alloys are determined by the size and shape of the primary phase $\alpha(\mathrm{Al})$ and the morphology of the eutectic $\alpha(\mathrm{Al})+\beta(\mathrm{Si})$. The closer the

Remigiusz Romankiewicz Ph.D. Eng., Ferdynand Romankiewicz Ph.D.D.Sc. Eng.: University of Zielona Góra, Faculty of Mechanical Engineering, Zielona Góra, Poland; r.romankiewicz@ibem.uz.zgora.pl 
content of silicon is to the eutectic in the alloy, the greater the impact of the construction of the eutectic on the properties of the alloy. Although the influence of the primary phase $\alpha(\mathrm{Al})$ decreases in this situation, it should not be omitted [1]. Achieving an advantageous state of the structure of hypoeutectic Al-Si alloy therefore requires modifying the interaction involving the dendrite fragmentation of the primary $\alpha(\mathrm{Al})$ phase and changing the morphology of the eutectic $\alpha(\mathrm{Al})+\beta(\mathrm{Si})$.

Among the theories explaining the mechanism of refining the solid solution $\alpha(\mathrm{Al})$, the three most-popular can be identified [2]:

- peritectic theory,

- boride theory,

- carbide theory.

According to the peritectic theory, $\alpha$ (Al) phase refinement causes the elements that form along with aluminum peritectic systems, especially titanium, zirconium, and niobium. Fragmentation of the phase $\alpha(\mathrm{Al})$ is the result of the peritectic reaction of the liquid metal with the primary phase $\mathrm{Al}_{3} \mathrm{Ti}$ according to the following equation:

$$
\text { liquid solution }+\mathrm{Al}_{3} \mathrm{Ti}=\alpha(\mathrm{Al})+\mathrm{Al}_{3} \mathrm{Ti}
$$

In boride theory, it is assumed that nucleation of the $\alpha(\mathrm{Al})$ phase can be caused by both the $\mathrm{TiB}_{2}$ boride and complex boride $(\mathrm{Al}, \mathrm{Ti}) \mathrm{B}_{2}$. The influence of $(\mathrm{Al}, \mathrm{Ti}) \mathrm{B}_{2}$ on the peritectic reaction [3] is also not excluded. Carbide theory binds the nucleation of the $\alpha$ (Al) phase to carbides with regular and hexagonal structural networks (especiall the TiC carbide). It is very interesting to see that one of the modified theories assumes that the $\mathrm{Al}_{3} \mathrm{Ti}$ layer is formed on the $\mathrm{TiB}_{2}$ boride particles directly or by the peritectic nucleation reaction of the primary $\alpha(\mathrm{Al})$ phase.

The views on the eutectic silicon refining mechanism as a result of sodium or strontium modification make it possible to isolate two popular theories; one of which concerns nucleation, and the other involves silicon phase growth. In the first theory, it is assumed that [4] sodium and strontium impede the nucleation of eutectic silicon by neutralizing the AIP phase particles that play the role of an active silicon nucleus. This theory (called the theory of poisoning the nucleus) only explains the increased degree of supercooling the modified Al-Si alloys but does not address the fibrous morphology of eutectic silicon solidification.

The second theory [5] relates to the growth of eutectic silicon and takes into account the possibility of changing the kinetics of this growth (the so-called kinetic effect) as well as the ability to inhibit the growth of certain planes of silicon crystals. In the first case, it is assumed that the presence of such surface-active elements (such as sodium or strontium in front of the crystallization front) makes the diffusion of silicon into the planes of the growing crystal difficult. In the second case, it is assumed that there is an adsorption of the modifying element atoms on the surface of the crystal-liquid phase; this is assumed 
to inhibit the growth of the privileged planes of silicon crystals for which the planes $\{111\}$ are considered.

The developed dendritic structure of phase $\alpha(\mathrm{Al})$ and lamellar eutectic silicon morphology limits the potentially achievable mechanical indexes of the AISi11 alloy. This disadvantageous structure of silumin can be changed by applying a double modification, which involves the simultaneous addition that ensures a refinement of the dendrites of a constant solution of $\alpha(\mathrm{Al})$ and additions that would change the morphology of the eutectic silicon from lamellar to fibrous $[1,6-8]$. The authors have decided to check the suitability of AIB4 and AISr10 pre-alloys for this purpose.

\section{Description of research}

Tests were carried out using the silumin AISi11 of the following chemical composition: $11.8 \% \mathrm{Si} ; 0.16 \% \mathrm{Fe} ; 0.012 \% \mathrm{Zn}$; below $0.01 \% \mathrm{Mn}$ and $\mathrm{Cu}$; the rest Al. The melting and modification processes were carried out in a graphite-chamotte melting crucible in a furnace chamber.

The modification process was carried out by overheating the metal bath to a temperature of $1003 \mathrm{~K}\left(730^{\circ} \mathrm{C}\right)$. The modifying additives included AIB4 and AISr10 master alloys. The modification processes lasted ten minutes. The modification conditions as well as the results of the experiments are presented in Table 1.

Table 1. Influence of modifiers on mechanical properties of silumin AISi11

\begin{tabular}{|c|l|c|c|c|}
\hline \multirow{2}{*}{$\begin{array}{c}\text { No. of } \\
\text { melt }\end{array}$} & \multicolumn{1}{|c|}{ Modifications conditions } & \multicolumn{3}{|c|}{ Mechanical properties } \\
\cline { 3 - 5 } & \multicolumn{1}{|c|}{$\begin{array}{c}\boldsymbol{R}_{\mathbf{m}^{\prime}} \\
\mathbf{M P a}\end{array}$} & $\begin{array}{c}\boldsymbol{A}_{\mathbf{5}} \\
\%\end{array}$ & HB \\
\hline 1 & without modification & 194 & 4.2 & 48 \\
\hline 2 & after modification with 0.25\% AISr10 & 209 & 7.4 & 51 \\
\hline 3 & after modification with 0.35\% AISr10 & 191 & 7.3 & 48 \\
\hline 4 & after modification with 0.25\% AIB4 & 198 & 10.1 & 51 \\
\hline 5 & after modification with 0.35\% AIB4 & 196 & 9.9 & 50 \\
\hline 6 & $\begin{array}{l}\text { after modification with 0.30\% AIB4 and 0.30\% } \\
\text { AlSr10 }\end{array}$ & 203 & 11.2 & 50 \\
\hline $7^{*}$ & after modification with 0.30\% AISr10 & 201 & 6.4 & 46 \\
\hline $8^{* *}$ & after modification with 0.30\% AISr10 & 216 & 13 & 51 \\
\hline $9^{* *}$ & $\begin{array}{l}\text { after modification with 0.30\% AIB4 and 0.30\% } \\
\text { AlSr10 }\end{array}$ & 212 & 6.8 & 48 \\
\hline
\end{tabular}

* test samples were cast one hour after introducing modifier master alloy into liquid melt

** test samples were cast two hours after introducing modifier master alloy into liquid melt 
In the case of the last three melts, the test samples were cast after one hour (7) and two hours ( 8 and 9 ) after the introduction of the modifiers to the liquid alloy.

The modification effects were evaluated based on macro- and microstructure changes and changes in the mechanical properties $\left(R_{m}, A_{5}\right.$, and $\left.\mathrm{HB}\right)$ of silumin. The mechanical properties of silumin were investigated on specimens cast in chill according to Polish Standards (PN-65/H-88003).

In the unmodified state, the AlSi11 silumin was characterized by a coarse-grained macrostructure (Fig. 1a) and large eutectic silicon plates in the microstructure (Fig.1b). Modification of the alloy with $0.25 \%$ AISr10 did not significantly change the macrostructure (Fig. 2a) but gives a good effect of the modification of eutectic $\alpha(\mathrm{Al})+\beta(\mathrm{Si})$, which is a change in the eutectic morphology of silicon to fibrous (Fig. 2b). Increasing the amount of the AISr10 additive to $0.35 \%$ did not change the structure of the silumin (Fig. 3a), but it ensured the improvement of the eutectic (Fig. 3b) while a few $\mathrm{SrAl}_{4}$ phase particles appeared in the microstructure.

Modification of the AISi1 1 silumin with 0.25\% AlB4 (Fig. 4a) and 0.35\% AIB4 (Fig. 5a) resulted in the very effective refinement of silumin grains without a noticeable change in the eutectic silicon morphology (Figs. $4 b$ and $5 b$ ).

Simultaneous modification of the alloy with additions of $0.30 \%$ AlB4 and $0.30 \%$ AISr10 (Fig. 6) resulted in the very efficient fragmentation of grains (Fig. 6a) and satisfactory refinement of the $\alpha(\mathrm{Al})+\beta$ (Si) eutectics (Fig. 6b).

The sample of AlSi11 silumin cast after one hour after modification with $0.30 \%$ AlSr10 (Fig. 7) showed no significant effect of the modification on the macrostructure (Fig. 7a) and a good effect of the improvement of the $\alpha(\mathrm{Al})+\beta($ Si) eutectics. A similar effect of silumin modification was observed for the cast sample two hours after modification (Fig. 8). A sample of silumin modified simultaneously with the addition of $0.30 \%$ AIB4 and $0.30 \%$ AISr 10 showed a very strong fragmentation of the silumin grains (Fig. 9a) and a very good effect of the improvement of the $\alpha(\mathrm{Al})+\beta(\mathrm{Si})$ eutectics (Fig. 9b). In the microstructure of this sample, a few particles of the $\mathrm{SrAl}_{4}$ phase were observed.

a)

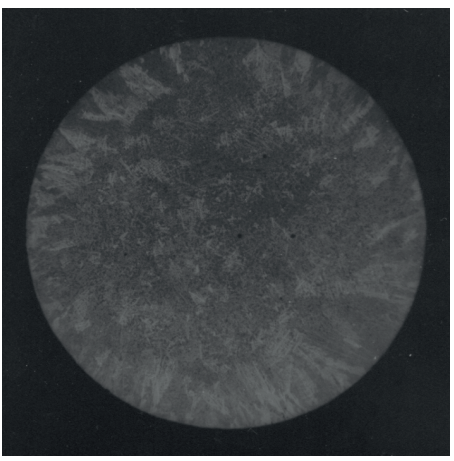

b)

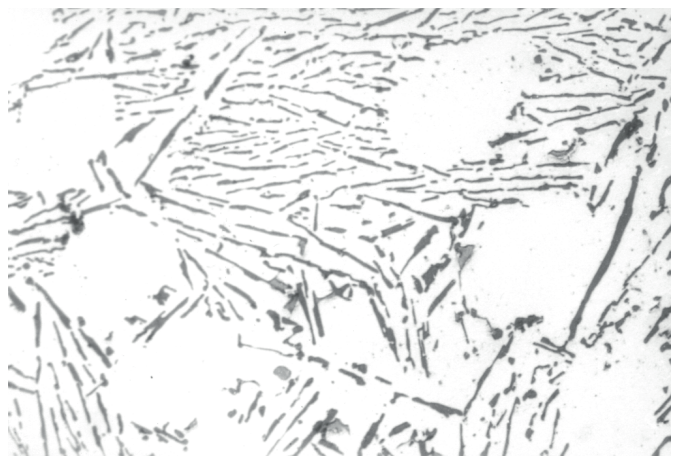

Fig. 1. Structure of silumin AlSi11 in non-modified state: a) macrostructure (magn. 1.5×); b) microstructure (magn. 500x) 
a)

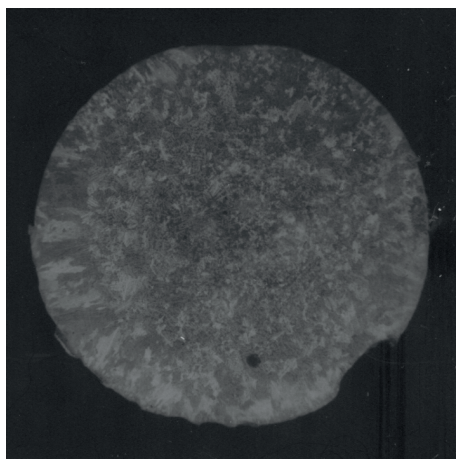

b)

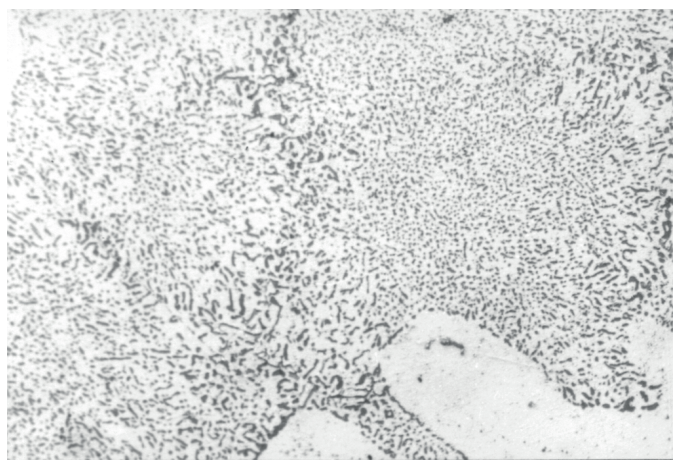

Fig. 2. Structure of silumin AlSi11 modified with addition of 0.25\% AISr10: a) macrostructure (magn. 1.5x); b) microstructure (magn. 500x)

a)

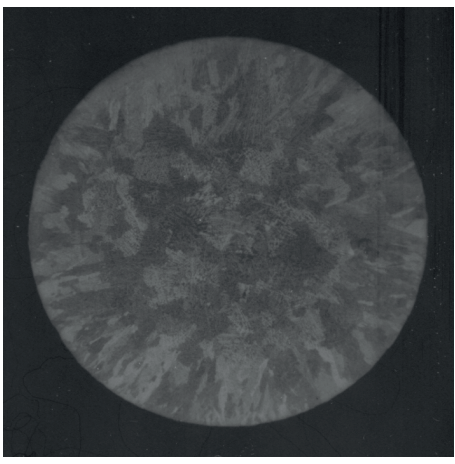

b)

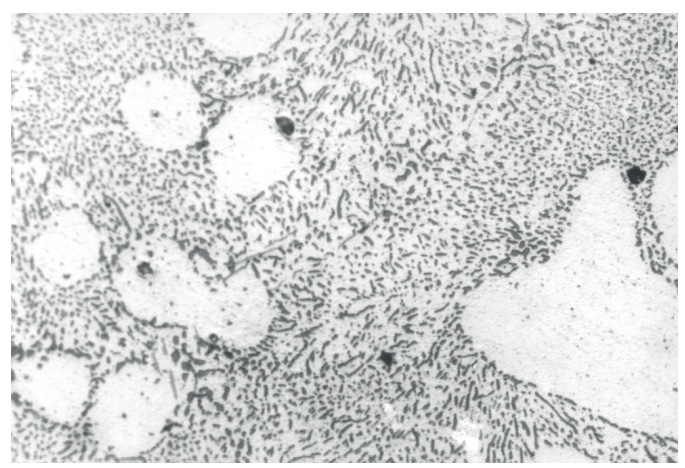

Fig. 3. Structure of silumin AlSi11 modified with addition of 0.35\% AISr10: a) macrostructure (magn. 1.5×); b) microstructure (magn. 500X)

a)

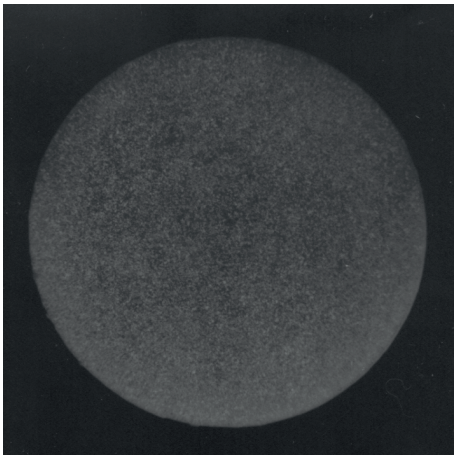

b)

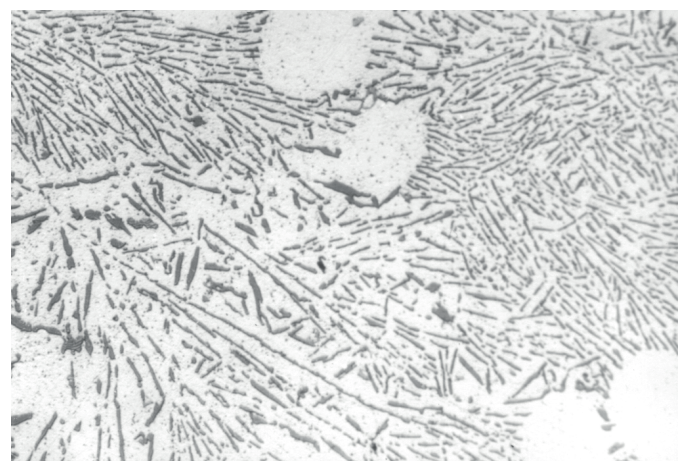

Fig. 4. Structure of silumin AlSi11 modified with addition of $0.25 \%$ AlB4: a) macrostructure (magn. 1.5×); b) microstructure (magn. 500x) 
a)

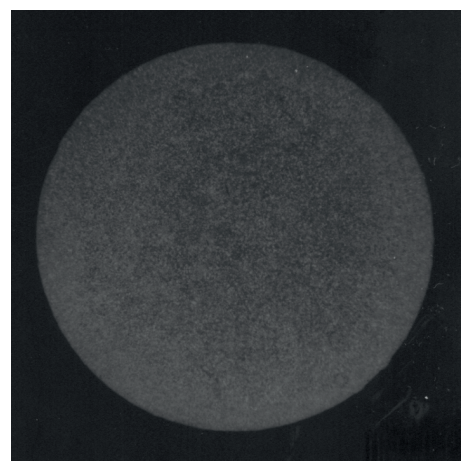

b)

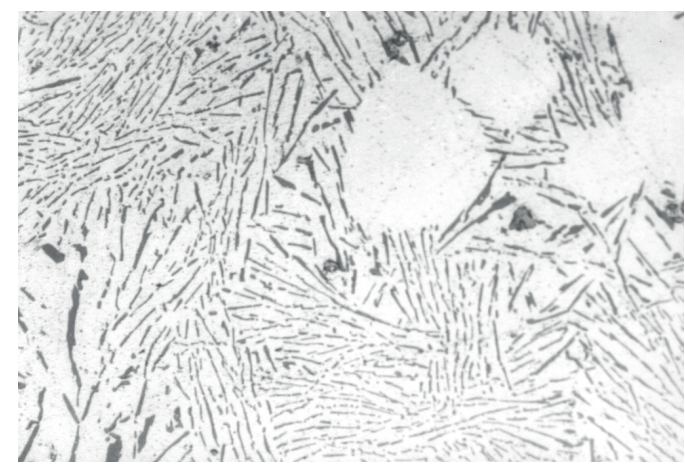

Fig. 5. Structure of silumin AlSi11 modified with addition of 0.35\% AlB4: a) macrostructure (magn. 1.5×); b) microstructure (magn. 500x)

a)

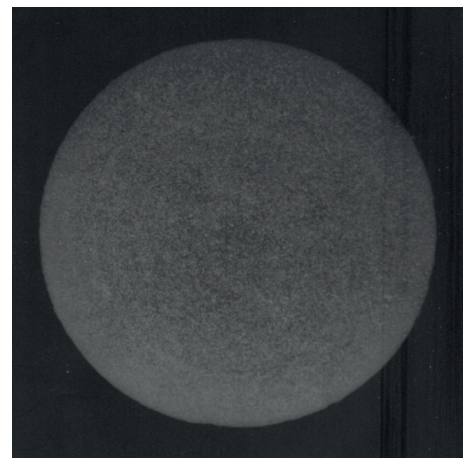

b)

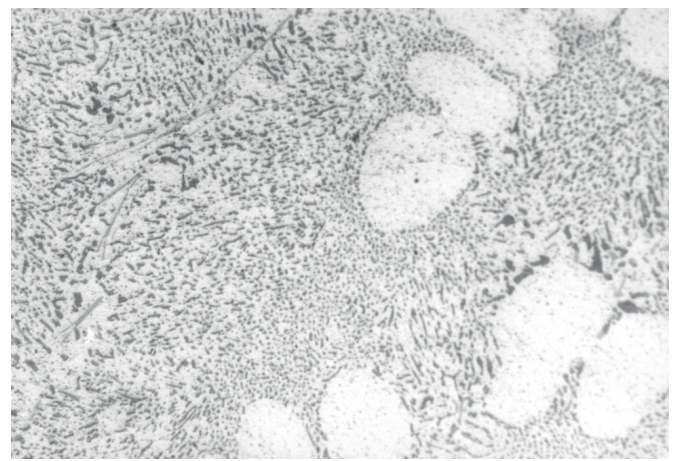

Fig. 6. Structure of silumin AlSi11 modified with additions of $0.30 \%$ AlB4 and $0.30 \%$ AlSr10: a) macrostructure (magn. 1.5×); b) microstructure (magn. 500x)

a)

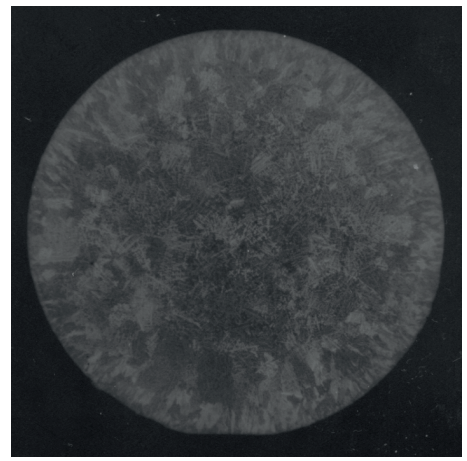

b)

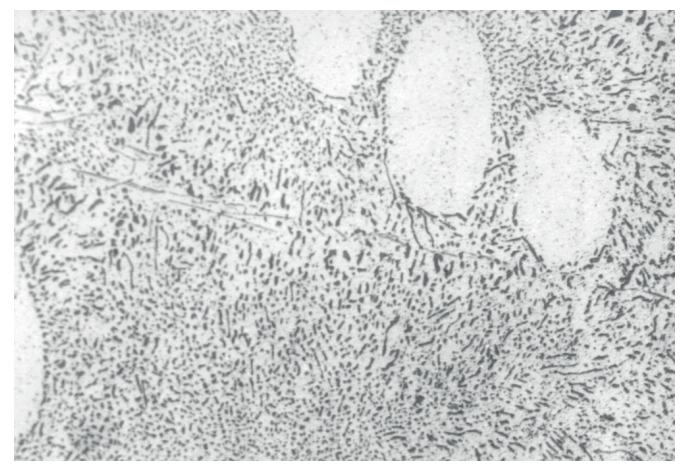

Fig. 7. Structure of silumin AlSi11 modified with addition of $0.30 \%$ AlSr10 cast one hour after modification: a) macrostructure (magn. 1.5x); b) microstructure (magn. 500x) 
a)

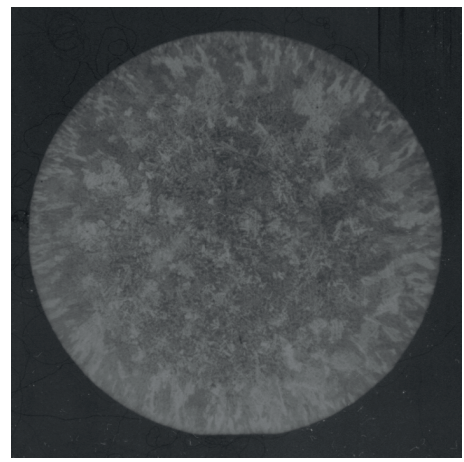

b)

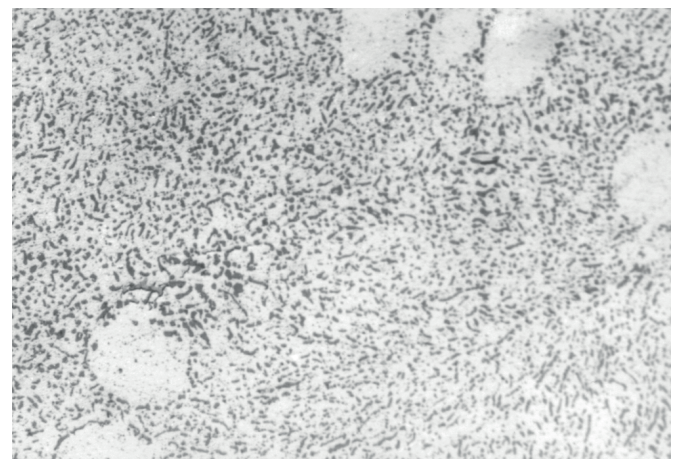

Fig. 8. Structure of silumin AlSi11 modified with addition of $0.30 \%$ AlSr10 cast two hours after modification: a) macrostructure (magn. $1.5 \times$ ); b) microstructure (magn. 500×)

a)

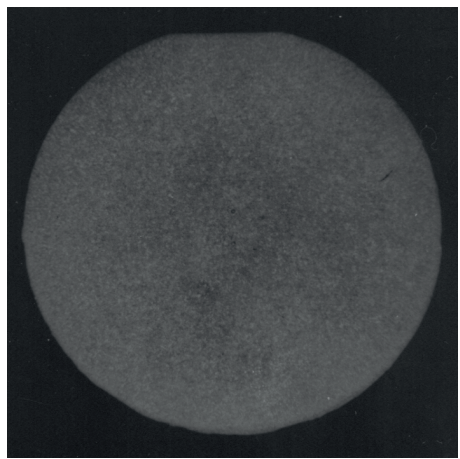

b)

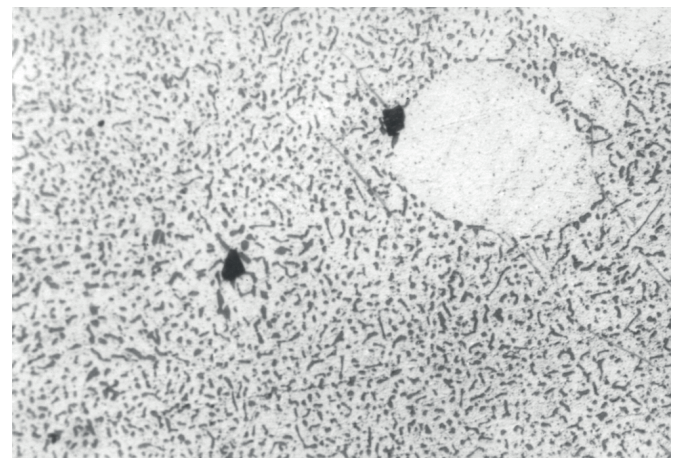

Fig. 9. Structure of silumin AlSi11 modified with additions of $0.30 \%$ AlB4 and $0.30 \%$ AISr 10 cast two hours after modification: a) macrostructure (magn. $1.5 \times$ ); b) microstructure (magn. 500×)

Modification of the AISi11 silumin in terms of structural changes caused changes in the mechanical properties (Tab. 1). Modification of the silumin by adding $0.25 \%$ AISr10 (Melt 2) resulted in an increase in tensile strength $R_{m}$ (from $194 \mathrm{MPa}$ to $209 \mathrm{MPa}$ ), a simultaneous increase in relative elongation $A_{5}$ (from $4.2 \%$ to $7.4 \%$ ), and a slight increase in hardness (from $48 \mathrm{HB}$ to $51 \mathrm{HB}$ ). Increasing the amount of the AISr10 additive to $0.35 \%$ (Melt 3) resulted in an increase of $A_{5}$ to $7.3 \%$ and a decrease of $R_{m}$ to $191 \mathrm{MPa}$ (so, to an $R_{m}$ level similar to the unmodified silumin. This may be indicative of an excess of the modifier, which is confirmed by the presence of $\mathrm{SrAl}_{4}$ phases in the microstructure of the silumin (Fig. 3b). Modification of the silumin with the addition of $0.25 \%$ and $0.35 \%$ AIB4 (Melts 4 and 5) resulted in an increase of the $R_{m}$ alloy samples to $198 \mathrm{MPa}$ and $196 \mathrm{MPa}$, respectively, with an increase of $A_{5}$ to $11.1 \%$ and $9.9 \%$, respectively. These indexes provide the basis for the finding that an addition of $0.25 \%$ AIB4 is sufficient to refine AISi11 
silumin grains, a noticeable improvement in $R_{m}$ and a favorable $A_{5}$ change (more than double). The simultaneous modification of silicone with $0.30 \%$ AlB4 and $0.30 \%$ AISr 10 (Melt 6) resulted in an increase of $R_{m}$ to $203 \mathrm{MPa}$ and $A_{5}$ to $11.2 \%$, with a slight increase in hardness to $50 \mathrm{HB}$.

Drawing the specimens of silumin modified with $0.30 \%$ AlSr10 after one hour after adding the modifier (Melt 7) showed a maintenance of $R_{m}$ of $201 \mathrm{MPa}$ with a satisfactory $A_{5}$ of $6.4 \%$. The casting of samples of silumin modified with $0.30 \%$ AlSr10 after two hours after adding the modifier (Melt 8) provided a high $R_{m}$ of $216 \mathrm{MPa}$ with a very good level of $A_{5}$ of $13 \%$. Modification of the silumin with $0.30 \%$ AlB4 and $0.30 \%$ AlSr10 (Melt 9) was carried out under similar conditions, providing a high $R_{m}$ of $212 \mathrm{MPa}$ with a satisfactory $A_{5}$ of $6.8 \%$. The reduced elongation may be due to the presence of the $\mathrm{SrAl}_{4}$ phase particles in the microstructure of the silumin (Fig. 9b).

Studies have shown that the AlSi11 alloy modified with an additive of strontium in the form of an AlSr10 master alloy ensured a good and lasting modification effect by enhancing by improvement of the $\alpha(\mathrm{Al})+\beta(\mathrm{Si})$ eutectic, resulting in an increase in the tensile strength $R_{m}$ and more than double the increase in $A_{5}$ elongation while keeping the hardness at a similar level. Research has also shown that increasing the amount of the AlSr10 master alloy to $0.35 \%$ can result in the formation of $\mathrm{SrAl}_{4}$ phase precipitation, which limits the effect of the modification, especially in terms of the impact on the tensile strength of the tested alloy.

Modification of AlSi11 silumin with a micro additive of boron in the form of an AlB4 master alloy results in a favorable increase (more than double) in the relative elongation of $A_{5}$, but the increase in tensile strength is slight despite the fine fragmentation of the grains in the modified alloy.

Simultaneous modification of silumin with AIB4 and AISr10 master alloys results in the strong grinding of silumin grains and satisfactory refinement of the $\alpha(\mathrm{Al})+\beta(\mathrm{Si})$ eutectic. As a result of this change in the structure of the silumin, the tensile strength and relative elongation are increased and maintained after the alloy has been held in a liquid state for two hours after adding the modifiers.

\section{Conclusions}

Modification of silumin AISi11 with a micro additive of strontium in the form of an AISr10 master alloy resulted in the improvement of eutectic $\alpha(\mathrm{Al})+\beta(\mathrm{Si})$ and a satisfactory increase in tensile strength and elongation after the addition of $0.25 \%$ of the modifier. Increasing the addition of $0.35 \%$ AlSr10 master alloy results in the formation of $\mathrm{SrAl}_{4}$ phase precipitation resulting in no expected increase in $R_{m}$.

Modification of the AlSi11 alloy with a micro additive of boron in the form of an AIB4 master alloy in the amount of $0.25 \%$ results in the strong refinement of silumin grains and improvement of the relative elongation and a slight increase of $R_{m}$. 
Modification of the AISi11 silumin using AIB4 and AISr10 master alloy additives simultaneously results in the high fragmentation of alloy grains and improvement of $\alpha(\mathrm{Al})+\beta(\mathrm{Si})$ eutectics, which results in a substantial increase of $R_{m}$ and $A_{5}$ in the tested alloy.

Modification of alloy AlSi11 with AISr10 and a simultaneous modification with AlSr10 and AlB4 master alloys ensure a satisfactory increase in tensile strength $R_{m}$ and relative elongation of $A_{5}$ by the casting of silumin samples after lasting two hours after the addition of modifiers.

\section{References}

[1] Müller K.: Möglichkeiten der Gefügebeeinflussung eutektischer und naheutektischer Aluminium-Silizium-Gußlegierungen unter Berücksichtigung der mechanischen Eigenschaften. Doktor-Ingenieur Dissertation, Technische Universität Berlin, 1995

[2] Körber K., Löhberg K.: Oberflächen- und Grenzflächenenergien von Aluminium-Silizium Schmelzen. Giesserei-Forschung, 23, 4 (1971), 173-177

[3] Crosley P., Mondolfo L.F.:The Modification of Aluminum Silicon Alloys. Modern Casting, 49 (1966), 53-64

[4] Hoefs P., ReifW., Schneider W.: Untersuchung einer neuen Kornfeinungsvorlegierung für Aluminum und Aluminium-Liegierungen. Giesserei, 12 (1994), 398-406

[5] Kremer M.: Einflu $\beta$ von Silizium auf die Kristallisation der $\alpha$-Primärphasein unbehandelten und korngefeinten, untereutektischen Aluminium-Silizium-Liegierungen. Doktor-Ingenieur Dissertation. Technische Universität Berlin, 1996

[6] Poniewierski Z.: Krystalizacja, struktura i właściwości siluminów. Wydawnictwa Naukowo-Techniczne, Warszawa 1989

[7] Wasilewski P.: Siluminy - modyfikacja i jej wpływ na strukturę i właściwości. Krzepnięcie Metali i Stopów, Solidification of Metals and Alloys, Z. 21, Polska Akademia Nauk, Katowice 1993

[8] Pietrowski S.: Siluminy. Politechnika Łódzka, Łódź, 2001 